\title{
A Cross-disciplinary Giant AT THE Crossroads OF AMERICA
}

\author{
RosS D. SILVERMAN, JD, MPH*
}

The state motto of Indiana is "Crossroads of America." Like the state in which she spent more than a quarter of a century as a professor, the work of Eleanor Kinney - a brilliant, prescient scholar, generous teacher, and founder and long-time leader of the William S. and Christine S. Hall Center for Law and Health - came to be known for its intersections of law, medicine, health policy, public health, and human rights. My appreciation of Eleanor began as something tribal: like Eleanor, I, too, had a background in law and public health, and I was a graduate of Indiana University. Over more than two decades, while I was faculty at Southern Illinois University and then following my move to Indianapolis, Eleanor became a colleague, mentor, and regular source of inspiration. She left a tremendous impression on me; I can safely say, were it not for Eleanor's influence on the field of health law, on my alma mater, and on me personally, I would not figuratively and literally, be where I am today.

Two areas of Eleanor's influence I feel most suited to highlighting in this special edition are her early leadership in Empirical Health Law and in discussing her professional contributions after retiring from Indiana University, especially her year as a visiting scholar at Southern Illinois University.

\section{AN EARLY LEADER IN EMPIRICAL HEALTH LAW}

In 2019, health law scholars regularly conduct grant-funded research informed by quantitative and qualitative analyses techniques drawn from health economics, health services research, public health, and the social sciences. More than thirty years ago, Eleanor looked around at the Indiana University-Purdue University-Indianapolis campus and noted that, within a few square blocks, she could cross the paths of faculty from the schools of medicine, nursing, dentistry, and social science (including sociology, economics, and psychology). She recognized that bringing together these different voices, with different viewpoints, experiences, and analytical approaches, would make for richer, more pragmatic, and more comprehensive scholarship and training for students. Through her grant-funded, multidisciplinary, multi-authored collaborations, resulting in publications in law reviews and reports developed by the Hall Center, Eleanor demonstrated early on how to break down silos to create diverse teams of colleagues and the value of empirics as a means both to inform new policy and to assess extant laws and practices.

For a researcher interested in studying issues related to medical malpractice and health care quality and safety, Indiana in the late 1980s offered an ideal laboratory. In an effort purportedly to contain the costs of malpractice insurance for Indiana providers and ensure continued access to care in the state, Indiana in

* Professor of Health Policy and Management, Indiana University Richard M. Fairbanks School of Public Health and Professor of Public Health and Law, Indiana University Robert H. McKinney School of Law. Address all communications to Professor Silverman at rdsilver@iu.edu 
1975 had implemented one of the nation's most restrictive malpractice compensation caps, as well as a Patient Compensation Fund and a Malpractice Review Panel. In 1987, Eleanor secured a Robert Wood Johnson Foundation grant to study the state's malpractice system. In a 1990-1991 piece published in the Indiana Law Review, Eleanor, collaborating with a sociologist colleague, published an analysis of the impact of the law on providers and claimants. ${ }^{1}$ The work begins with Eleanor and her co-authors offering a "traditional" law reviewstyle analysis of the subject, critiquing recent court decisions interpreting the law's application. ${ }^{2}$ It then moves into the world of empirical studies: collecting the more than 6000 malpractice claims filed with the state's Department of Insurance from 1975 to 1988, conducting an independent quantitative analysis of this data, contrasting their results with results reported in other states and in a contemporary General Accounting Office report, and then - using both their own analysis and qualitative information collected from claimant reports on their experience in the Indiana malpractice system - discussing the sometimes counterintuitive impact of the law on all parties involved. ${ }^{3}$ It is a sober, datadriven critique of "the most comprehensive and severe set of insurance and tort reforms in the nation," ${ }^{\prime 4}$ and a wonderful early example of mixed empirical methods in law scholarship.

Thanks to Eleanor's commitment to conducting data-driven research, and her building of collaborations across the many health professional schools on the Indianapolis campus, the Hall Center became both a hub and a champion of empirical health law studies, focused on "enhanc[ing] access to high-quality care for the most vulnerable of our society who are often excluded from the tremendous capabilities and services of the American health care system." ${ }^{5}$ As she and David Orentlicher state in a piece celebrating the Hall Center's 10th Anniversary:

Since 1987, the Center has engaged in many empirical studies addressing such topics as Medicare coverage policy, quality improvement for community-based, long-term care, barriers to health insurance for people with serious illness and designing strategies for expanding health coverage for the working poor. In addition, Professor Kinney has conducted many studies of grievance and appeal procedures as well as rule and policy asking procedures for the Medicare and Medicaid programs with support from the Administrative Conference of

1. Eleanor D. Kinney, William P. Gronfein \& Thomas P. Gannon, Indiana's Medical Malpractice Act: Results of a Three-Year Study, 24 InD. L. REV. 1275 (1991).

2. Id. at 1281-85.

3. See id. at $1285-1305$.

4. Id. at 1302 .

5. Eleanor D. Kinney \& David Orentlicher, Lies, Damn Lies and Statistics: How Empirical Research Shapes Health Law and Policy, A Symposium in Celebration of the Tenth Anniversary of the Center for Law and Health Symposium: Introduction, 31 IND. L. REV. 9, 10 (1998). 
the United States. ${ }^{6}$

Eleanor sought to overcome the limitations of traditional health law scholarship that would focus its policy analysis where the lights were brightest. Even today, as we build out the field of legal epidemiology, surveillance will frequently focus on analyzing the "black letter law" of statutory and regulatory sources. Two decades ago, she described the critical, under-examined role of private entities in forming and shaping health policy. As she notes:

Understanding how private organizations make policy is essential as policy is used extensively in many contexts ...

Yet policy science and legal scholarship have accorded little attention to how private organizations make policy that is used in public benefit and regulatory programs or otherwise affects important aspects of national life. [Focusing instead on] how interest groups exert influence on legislative and regulatory bodies and what legislators, regulators, and judges do as a result.

...

.. . [L]egal and social science scholarship to date have not really described or examined critically the policy making processes of private organizations. This gap is troubling given the importance of private policy on nearly all aspects of public life. ${ }^{7}$

Drawing upon her experience with medical malpractice regulation, health care quality, and health services research, Eleanor in 1999 was one of the early health law scholars to take interest in what Eccles and Mittman would, some seven years later, introduce as the field of Implementation Science, "the scientific study of methods to promote the systematic uptake of research findings and other evidence-based practices into routine practice, and, hence, to improve the quality and effectiveness of health services," as facilitated through policy.

Using the example of diabetes management policy, she outlines the process through which scientific insights into disease pathways find their way into clinical practice, then evolve into practice guidelines and quality standards promoted by private medical organizations, then get translated into quality performance measures imposed by private accrediting bodies, then are used by health insurers to enforce practice standards, ${ }^{9}$ and then may eventually make their way into statutes and regulations (which can then be assessed for their effectiveness). Eleanor recognized early on the value of empirical, "evidencebased" policymaking and policy analysis. To borrow a quote from my legal

6. Id. at 9 .

7. Eleanor D. Kinney, Behind the Veil Where the Action Is: Private Policy Making and American Health Care Recent Developments, 51 AdmIN. L. REV. 145, 150-51 (1999).

8. Martin P. Eccles \& Brian S. Mittman, Welcome to Implementation Science, 1 IMPLEMENTATION SCI. 1 (2006).

9. Kinney, supra note 7, at 180-83. 
epidemiology colleagues, writing a dozen years later, Eleanor understood early on that "What Gets Measured, Gets Changed." throughout her career to promote opportunities to bring empirically-grounded fields like Health Services Research into legal scholarship in order to develop evidence-informed and evidence-driven health policy. ${ }^{11}$

I feel one of the most important empirical studies Eleanor conducted was one she published in 2004. Building on her 2001 piece (originally a lecture), "The International Human Right to Health: What Does This Mean for Our Nation and World Lecture," 12 Eleanor (with co-author Brian Clark), published "Provisions for Health and Health Care in the Constitutions of the Countries of the World" in the Cornell International Law Journal. ${ }^{13}$ This tour de force represents an early, highly influential example of Public Health Law research, ${ }^{14}$ or what we now call Legal Epidemiology Scholarship ${ }^{15}$ or Policy Surveillance. ${ }^{16}$

Inspired by her philosophical belief in society assuring some form of right to health care for vulnerable populations (even if not guaranteed under U.S. jurisprudence), and building upon expanding international support for the human right to health, Eleanor and her co-author looked at the Constitutions of United Nations member-states to assess whether state Constitutions explicitly conferred

10. See Jamie F. Chriqui, Jean C. O’Connor \& Frank J. Chaloupka, What Gets Measured, Gets Changed: Evaluating Law and Policy for Maximum Impact, 39 J.L. MED. \& ETHICs Supp. 1 21 (2011).

11. See, e.g., Eleanor D. Kinney, Prospects for Comparative Effectiveness Research under Federal Health Reform, 21 AnNals Health L. 79 (2012).

12. Eleanor D. Kinney, The International Human Right to Health: What Does this Mean for Our Nation and World Lecture, 34 IND. L. REV. 1457 (2001).

13. Eleanor D. Kinney \& Brian Alexander Clark, Provisions for Health and Health Care in the Constitutions of the Countries of the World, 37 CoRnELL INT'L L.J. 285 (2004).

14. See generally Scott Burris, Alexander C. Wagenaar, Jeffrey Swanson, Jennifer K Ibrahim, Jennifer Wood \& Michelle M Mello, Making the Case for Laws That Improve Health: A Framework for Public Health Law Research, 88 MiLbANK Q. 169, 172 (2010) (contrasting the concept of Public Health Law "Research" - "the use of systematic [, generally empirical,] methods within an explicit theoretical framework to collect and analyze data" from Public Health Law "Scholarship" - research on legal issues in public health grounded in nonempirical fields such as philosophy, ethics, or legal analysis).

15. See generally Tara Ramanathan, Rachel Hulkower, Joseph Holbrook \& Matthew Penn, Legal Epidemiology: The Science of Law. 45 J.L. MED. \& ETHICS Supp. 1 69, 69 (2017) (explaining legal epidemiology as a form of transdisciplinary, systematic public health law research defined as "the scientific study and deployment of law as a factor in the cause, distribution, and prevention of disease and injury in a population").

16. See generally Scott Burris, Laura Hitchcock, Jennifer Ibrahim, Matthew Penn, \& Tara Ramanathan, Policy Surveillance: A Vital Public Health Practice Comes of Age, 41 J. Health Pol. POL'Y \& L. 1151, 1151 (2016) (defining policy surveillance as "the systematic, scientific collection and analysis of laws of public health significance." It is the most rigorous form of legal epidemiology research). 
a right to health or health care to their people. ${ }^{17}$ They then examined whether states conferring such rights backed up these Constitutional proclamations with further action. ${ }^{18}$ They created a typology of five different types of Constitutional provisions addressing health or health care: aspirational statements, entitlement statements, statements of duty, statements referring to specific approaches to delivering health services, and statements incorporating international and/or regional treaties recognizing a human right to health. ${ }^{19}$ They found that two-thirds of all nation's constitutions contained a provision addressing health or health care.$^{20}$ However, they also found that (a) the absence of such a Constitutional provision did not also mean the absence of support for such services through other state policies; in fact, they found a number of states that extensively supported their citizens' health despite not having such a commitment in their highest law; and (b) "not all of the countries that have provisions regarding health and health care in their constitutions have in practice lived up to these mandates. Some of the most resounding constitutional commitments to health and health care are in poor countries with tenuous democracies" and scant investment in health infrastructure. ${ }^{21}$ In fact, their empirical analysis found an obverse correlation:

The number or strength of constitutional provisions does not appear to have a determinative role in the amount of resources that countries spend for the health care of their populations. Specifically, countries that expressed the greatest constitutional commitment to health-evidenced by inclusion of both a statement of entitlement and duty - had an average government per capita expenditure for health care of $\$ 308$ in 2000 . However, the same average for countries that had no provision regarding health or health care was $\$ 716.95 .{ }^{22}$

While Eleanor and her coauthor were not surprised by this finding, they did feel that the widespread inclusion of such constitutional provisions served as both progress toward universal international recognition of a human right to health, as well as a policy imperative for those underperforming countries to pursue. ${ }^{23}$

This article's integration of issues of health law, policy, and human rights, and its use of empirical analytical techniques to hold states accountable for the implementation of promises expressed in law, has been a significant influence on and inspiration to me as a scholar. Cited nearly 200 times, it also has been widely appreciated by legal, medical and human rights scholars around the globe.

17. Kinney \& Clark, supra note 13, at 291-93.

18. Id. at 294-98.

19. Id. at $189-90$.

20. Id. at 287.

21. Id.

22. Id. at 295 .

23. Id. at 298 . 


\section{A MODEL FOR LIFE-LONG LEARNING}

Eleanor's May 2011 retirement from Indiana University was not her final chapter as a teacher or scholar. It would be enough to say that Eleanor was committed to lifelong growth and learning, but I believe there was more to it than that. Having spent decades analyzing public health insurance, health care quality and safety, and health reform, she was not about to sit silently by and watch as the Affordable Care Act transformed American health care.

In 2012-2013, she joined me as a colleague at Southern Illinois University, where she was named that academic year's Garwin Distinguished Visiting Professor of Law and Medicine. While at SIU, she taught multiple courses and delivered several public lectures, all of which focused on inspiring her listeners to understand how health law can protect society's most vulnerable and to be advocates for their clients and patients, as well as their professions. She offered law school courses in the Law of the Medicare Program and Health Policy Law, as well as a seminar on Health Reform Topics. These courses were practically oriented, helping her students prepare for a future of answering difficult client questions at the intersection of multiple disciplines. As I served as Editor-in-Chief of the Journal of Legal Medicine, which at the time was affiliated with Southern Illinois University School of Law, I also saw how her work resonated with our most engaged health law students and translated into publications inspired by her tutelage. ${ }^{24}$ She also shared her enthusiasm for international health law with our students deep in rural southern Illinois, bringing them a course on Health and Human Rights in a Global Market that examined how international regulatory bodies and agreements affected issues of intellectual property, drug and device marketing, and the human right to health.

In addition to offering her the opportunity to discuss national issues such as the implementation of the Affordable Care Act, Eleanor's new location 200 miles southwest of Indianapolis gave her a fantastic vantage point to observe and comment upon contentious developments in another core area of her expertise, medical malpractice. While Indiana had a very stringent, practically unassailable cap on damages in place for three decades, in February 2010, the Illinois Supreme Court struck down its compensatory damage cap. ${ }^{25}$ This opened up a heated political battle. ${ }^{26}$ One that was still raging as Election Day 2012 approached. On September 27, 2012, Eleanor delivered the Dr. Arthur Grayson Distinguished Lecture to the Carbondale community. ${ }^{27}$ Her lecture, titled "Physicians and

24. See Erin Bradley, Accountable Care Organizations Antitrust Guidelines Will Not Save Rural Providers, 34 J.L. MED. 295 (2013).

25. Lebron v. Gottlieb Memorial Hospital, 930 N.E.2d 895 (Ill. 2010).

26. Sean Stonefield, A Third Strike for Tort Reform, CHI. TRIB. (Dec. 8, 2011), https://www.chicagotribune.com/chi-tort-reform-20111208-story.html [https://perma.cc/WR53$\mathrm{G} 7 \mathrm{BH}]$.

27. Greyson Lecture-Past Programs, Southern ILL. Sch. OF L., https:/law.siu.edu/ academics/center-programs/health-law-policy/grayson-lecture-past.html [https://perma.cc/U3FQNTBG]. 
Health Law at an Impasse: What Can Be Done?" spoke directly to the instability area physicians felt concerning malpractice as well as health care reform. ${ }^{28}$

The following Spring, Eleanor traveled to Springfield, Illinois to deliver the Theodore R. LeBlang Distinguished Lecture before a full auditorium of faculty, students, and staff at Southern Illinois University School of Medicine. ${ }^{29}$ The lecture, titled "The Affordable Care Act: What's in it for Physicians," ${ }^{30}$ was delivered as part of the School of Medicine's fourth-year medical school curriculum on The Physician and Society, when students would have an opportunity to gain a greater understanding of the regulation of the U.S. healthcare system, the social determinants of health, and their role as advocates for their profession, their patients, and their communities. The lecture was a tour de force, tracing the history of the corporate transformation of the U.S. healthcare system, describing the ever-increasing layers of oversight and bureaucracy those systems impressed upon physician practices, and sharing her prediction that the most impactful component of the Affordable Care Act would be its facilitation of value-driven Accountable Care Organizations. She closed the lecture with a call for physicians to take back clinical control of the content and quality of medical care, encouraging them to step up and take on stronger roles in political and corporate health care settings.

She continued to publish following her Indiana University retirement, including three law review articles, ${ }^{31}$ a book on health care reform, ${ }^{32}$ a Nutshell book on Administrative Law of Health Care, ${ }^{33}$ an article on Administrative Law and Medicare, ${ }^{34}$ and articles on medical malpractice, access to care, and medical device regulation. Eleanor Kinney is a role model for lifelong learning and commitment to making an intellectual impact.

28. Id.

29. Lecture Archive, SIU Sch. Of Med, https://www.siumed.edu/medhum/lecturearchive.html [https://perma.cc/FDH2-RPU9].

30. Id.

31. See Eleanor D. Kinney, Prospects for Comparative Effectiveness Research under Federal Health Reform, 21 Annals Health L. 79 (2012); Eleanor D. Kinney, The Affordable Care Act and the Medicare Program: Linking Medicare Payment to Quality Performance, 68 N.Y.U. ANN. SuRV. AM. L. 567 (2013); Eleanor D. Kinney, The Affordable Care Act and the Medicare Program: The Engines of True Health Reform, 13 Yale J. Health Pol'y L. \& Ethics 253 (2013).

32. See Eleanor D. Kinney, The Affordable Care Act and Medicare in Comparative CONTEXT (2015).

33. See Eleanor D. Kinney, Administrative law of Health Care in a Nutshell (2017).

34. See Eleanor D. Kinney, The Accidental Administrative Law of the Medicare Program, 15 Yale J. Health Pol'y L. \& Ethics 111 (2015). 